\title{
ANALYSIS OF THE POSSIBILITY OF USING NON-CALIBRATED NOISE MEASUREMENT SYSTEMS (SMARTPHONES) FOR MACHINE DIAGNOSTICS
}

\author{
ADAM MAŃKA ${ }^{1}$, ANDRZEJ HELKA ${ }^{2}$, ANNA KULA ${ }^{3}$ \\ ${ }^{1}$ Silesian University of Technology, Faculty of Transport and Aviation Engineering, Department of Railway \\ Transport, Krasińskiego 8 str., 40-019 Katowice, Poland, adam.manka@ polsl.pl \\ ${ }^{2}$ Silesian University of Technology, Faculty of Transport and Aviation Engineering, Department of Railway \\ Transport, Krasińskiego 8 str., 40-019 Katowice, Poland, andrzej.helka@ polsl.pl \\ ${ }^{3}$ Silesian University of Technology, Faculty of Transport and Aviation Engineering, Krasińskiego 8 str., \\ 40-019 Katowice, Poland, annakul441@ @student.polsl.pl
}

\begin{abstract}
Summary
The article presents an analysis of the possibility of using a smartphone for sound recording and analysis in relation to reference measurements carried out with laboratory equipment. The scope of the possibility of using recordings by non-calibrated noise measurement (smartphones) was presented, along with limitations and additional requirements that must be met so that such a measurement could be used for further analysis.
\end{abstract}

Keywords: sound measurement and analysis, smartphones, vibrodiagnostics, rail transport, train

\section{ANALIZA MOŻLIWOŚCI WYKORZYSTANIA NIEWZORCOWANYCH SYSTEMÓW POMIARU HAŁASU (SMARTFONÓW) DO CELÓW DIAGNOSTYKI MASZYN}

\section{Streszczenie}

W artykule przedstawiono analizę możliwości wykorzystania smartfonu do rejestracji i analizy dźwięku w odniesieniu do pomiarów referencyjnych przeprowadzonych sprzętem klasy laboratoryjnej. Przedstawiono zakres możliwości wykorzystania nagrań przez systemy niekalibrowane (smartfony) wraz z ograniczeniami i dodatkowymi wymaganiami, które należy spełnić, aby taki pomiar mógł zostać wykorzystany do dalszej analizy.

Słowa kluczowe: pomiar i analiza dźwięku, smartfon, telefon, wibrodiagnostyka, transport kolejowy, pociąg

\section{INTRODUCTION}

The possibility of an effective study of the phenomenon related to the construction and operation of machines is undoubtedly conditioned by the possibility of carrying out measurements. Conducting measurements undoubtedly requires an appropriate test methodology and calibrated measuring equipment.

This is especially true for noise and vibration measurements, which use measurement lines consisting of the highest class sensors microphones, amplifiers, recorders, filters, and even appropriate cables connecting these elements. Negligence in this respect may very often lead to errors in measurements and, consequently, to the inability to conduct an analysis or, even worse, to incorrect conclusions from the research.

The measurement with non-calibrated systems, including smartphones, indicated in the title, in no way constitutes an attempt to replace the classic methods of research. However, it is possible to indicate whether and to what extent the performance of such measurements or the analysis of the recorded sound with the use of very common smartphones brings any information that could be used for diagnostic purposes and if so, what conditions must be met.

It should be borne in mind that there are situations in which the sound is registered by an outsider and its analysis, for example, constitutes evidence in court or is the basis for shutting down the device from operation and conducting diagnostic tests. Measurements of this type could theoretically be used for detection or identification purposes where an accurate quantitative measurement is not necessary. The undoubted advantage of using noncalibrated systems is their relatively low cost and universal access. Therefore, it creates the theoretical possibility of a very wide, or even mass use of this equipment for preliminary diagnostic tests. 
Therefore, the aim of these studies was to determine whether and under what conditions, it is possible to use non-calibrated measurement systems (including smartphones) to obtain reliable measurement data used for machine diagnostics.

The research was conducted using the authors' own equipment and calibrated measurement systems of the Department of Rail Transport, Faculty of Transport and Aviation Engineering, Silesian University of Technology. The experimental research was part of the co-author's engineering project. The research was carried out to determine the possibility of diagnosing rail vehicles, therefore the subject of the research and their methodology are directly related to the requirements for this transport industry.

\section{ANALYSIS OF THE CURRENT STATE OF KNOWLEDGE ON THE USE OF NON- CALIBRATED SOUND ANALYSIS SYSTEMS FOR TECHNICAL PURPOSES}

In the literature, there can be found numerous literature sources that indirectly present similar problems of sound analysis with the use of noncalibrated systems, namely smartphones.

In the article [1] the authors present tests of both the hardware itself, i.e. smartphones, in terms of sound recording, and software - applications that enable the measurement and recording of sound noise. In the case of smartphones themselves, the recording of a given sound is related to the quality of the microphone and AD/DA converters used and the type of audio codec used. The article [2] presents the possibilities of using a smartphone for acoustic detection and diagnosis of bearing faults. The article [1] presents the possibilities of using smartphones for voice recording and on this basis making a patient's diagnosis for laryngeal cancer. It has been shown that at the moment both mobile devices and appropriate applications provide such a good quality of sound recording that they can be used for initial remote diagnosis of patients. On the other hand, the authors of this publication are interested in recording not so much the sound in terms of its quality, but the measurement and recording of the noise itself in order to determine its intensity as a function of time and possible use for diagnostic analyzes. Therefore, below are examples of two teams that performed noise measurements with the use of different phone models and the use of different mobile applications $[3,4]$.

An article from Noise and Health magazine [4] presents the results of measurements taken with the Apple iPhone 4S using 5 different noise measurement applications: DB volume, Advanced Decibel, SPLnFFT Noise Meter, SPL and SoundMeter. In addition, the results were compared with that of a sound meter with accuracy class 1 . The authors drew attention to the fact that the inaccuracies of the measurement results may result from inadequate definition of the $\mathrm{A}$ and $\mathrm{C}$ correction curves. Based on the measurements, it was found that only one of the five tested applications has an accuracy within $5 \mathrm{~dB}$ and it is SoundMeter. In other cases, the results obtained during measurements with the telephone were overstated in relation to those obtained with the calibrated meter. The authors of the article recommend using the calibration option before taking measurements, if the application allows it. It should be noted that in the case of research by the authors of this publication, calibration is an essential element to determine a reliable sound pressure level at a given measurement time. The results obtained by the SoundMeter app differed by $1-2 \mathrm{~dB}$ from the results indicated by the Class 1 sound meter for sound levels up to $80 \mathrm{~dB}$ and frequencies of 1, 2, 4, 8kHz. For low frequencies 250 and $500 \mathrm{~Hz}$ and for the sound level above $80 \mathrm{~dB}$ and frequencies $1,2,4,8 \mathrm{kHz}$, the differences in the results were greater, ranging from 5 to $10 \mathrm{~dB}$. Other applications increased the results from 3 to $10 \mathrm{~dB}$ depending on the set frequency and measured sound level. The authors of the publication [5] also obtained a very good convergence of the results of sound level measurements using smartphones for low frequencies, ie from $250 \mathrm{~Hz}$. The authors indicate, however, that at frequencies higher than $2 \mathrm{kHz}$, the differences from the reference signal start to get bigger. Another article from The Journal of the Acoustical Society of America [3] presents the test results of 10 sound measurement apps for iOS and 4 for Android. The Android systems are: SPL meter by AudioControl, deciBel Pro by BSB Mobile Solutions, dB sound meter by Darren Gates and NoiseMeter by JINASYS. Measurements were made using 9 mobile devices: iPhone 3GS, iPhone 4S, iPhone 5, iPad 4th generation, Samsung Galaxy S3, Samsung Note, Samsung Focus, HTC One X and Motorola Droid RAZR. The measurement results indicated two applications with an average difference of $0.52 \mathrm{~dB}(\mathrm{~A})$. There were also those that showed differences of as much as $62 \mathrm{~dB}$. The test generated noise in the frequency range from $20 \mathrm{~Hz}$ to $20 \mathrm{kHz}$ with the level from $65 \mathrm{~dB}$ to $95 \mathrm{~dB}$ in $5 \mathrm{~dB}$ steps. Based on the obtained results, it was found that the SoundMeter application was the closest to the real values. The mean difference was $0.52 \mathrm{~dB}(\mathrm{~A})$. For the Noise Hunter, NoiSee, and SoundMeter applications, the differences were within $+-2 \mathrm{~dB}(\mathrm{~A})$ from the standard. The selected publications presented above show the possibility and sense of using a smartphone in special diagnostic cases with an appropriate application (preferably one that can be calibrated) for measuring and recording sound intensity. There are also publications in the literature presenting the methodology of professional calibration of the sound measurement module in a smartphone [6]. Smartphones, thanks to various sensors installed in them, find a number of serious applications, not only technical, but also particularly responsible for non-technical ones, eg for monitoring important physiological parameters of 
people, detection of posture and fall related to health monitoring has gained enormous popularity $[7,8]$.

The huge scope of using the possibilities offered by smartphones to conduct advanced analyzes in various areas of life and science is presented in articles $[9,10]$. In addition to smartphones, there is a tendency to use other popular - easily available hardware solutions, e.g. based on Arduino, also in other fields of technology, e.g. related to transport for analysis [11].

\section{REQUIREMENTS FOR NOISE MEASUREMENT IN RAIL TRANSPORT}

The issues of measuring and limiting transport noise, especially in large agglomerations, are gaining more and more importance [12]. All requirements related to the admission to use of railway vehicles in the European Union countries are regulated by the provisions called the Technical Specifications for Interoperability, i.e. TSI. They are divided into five subsystems: Infrastructure, Energy, Rolling Stock, Trackside Control-Command and Signaling and OnBoard Control. Thus, the requirements for meeting the relevant criteria by railway vehicles in terms of noise are also included in these regulations, specifically in the rolling stock subsystem. The analysis of legislative changes taking place in the provisions of TSI (until 2005) in the field of environmental protection for the rolling stock was shown in the work [13]. It also presents the requirements for the measurement methodology and noise limit values. Initially, the TSIs only dealt with high-speed rail [14]. After a few years, it was also extended to conventional railways [15]. The latest TSI changes were introduced on June 16, 2019. [16].

The latest TSI regulations [16] on noise, coming with the 4th railway package, introduce some changes regarding the technical requirements related to noise measurement. The table below (Table 1) summarizes the current values of pass-by noise for individual types of railway vehicles, based on the presentation of the Railway Institute [17], which also lists the latest regulations in this regard.

Table 1. List of acceptable values of equivalent sound levels permitted in TSI for railway vehicles (at $80 \mathrm{~km} / \mathrm{h}$ )

\begin{tabular}{|c|c|}
\hline Type of vehicle & $\begin{array}{c}\text { Pass-by noise } \\
\text { LpAeq,Tp }(80 \mathrm{~km} / \mathrm{h}) \mathrm{dB}\end{array}$ \\
\hline Locomotives with electric drive & 84 \\
\hline Locomotives with diesel drive & 85 \\
\hline Electric multiple units & 80 \\
\hline Diesel multiple units & 81 \\
\hline Passenger wagons & 79 \\
\hline Freight wagons & 83 \\
\hline
\end{tabular}

The standards for the permissible noise level and methods of its measurement are defined as already mentioned in the TSI and in the European ISO standards. For measurements of the noise of railway vehicles passing, the standard [18] may be used, and for measurements of noise inside railway vehicles, the standard [19]. In order to compare the noise of a railway vehicle passing with the limit values, the equivalent sound intensity level in $\mathrm{dB}$ (A) LpAeq, T is determined, which is measured during the journey at a distance of $7.5 \mathrm{~m}$ from the track axis and $1.2 \mathrm{~m}$ above the rail head surface. The measurements are performed for the speed of $80 \mathrm{~km} \mathrm{/} \mathrm{h} \mathrm{and} \mathrm{the}$ maximum speed [13, 17, 18].

The train passing time (Tp) is counted from the moment the head of the train passes in front of the microphone until the back of the train passes through the same place. The standards also define the time interval, marked as $\mathrm{T}$, which starts from the moment when the sound level is $10 \mathrm{~dB}$ lower than when the head of the train passes the microphone position and similarly ends when the sound level is $10 \mathrm{~dB}$ lower than at the time of the ride. back of the train through the same place. The difference between the times $\mathrm{T}$ and Tp is illustrated in Figure 1 below.

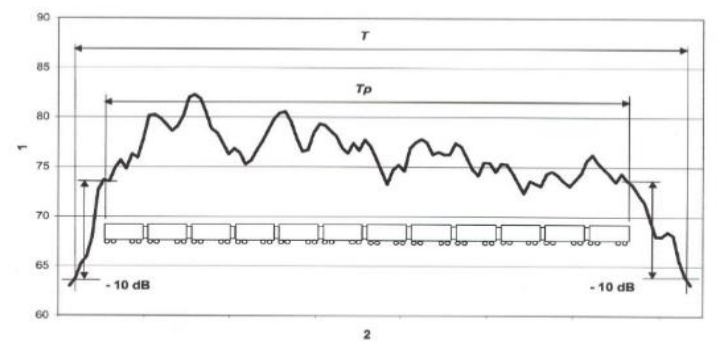

Fig. 1. Time taken for noise measurements [20] Axis description: 1 - sound pressure level corrected according to the A frequency characteristic, $\mathrm{dB}, 2$ - time, $\mathrm{s}$

Another important concept is the A-weighted sound level $\mathrm{L}_{\mathrm{Aeq}, \mathrm{Tp}}$ and it is given by:

$$
L_{p A e q, T_{p}}=10 \lg \left(\frac{1}{T_{2}-T_{1}}\right) \int_{T_{1}}^{T_{2}}\left(\frac{p_{A}^{2}(t)}{p_{0}^{2}} d t\right) d B
$$

where:

- $T_{p}=T_{2}-T_{1}$ prescribed time for the train pass, $s$;

- p_A (t) instantaneous sound pressure corrected according to A characteristic, $\mathrm{Pa}$;

- $\mathrm{p}_{0}$ reference sound pressure of 2·10-5 Pa.

- A more practical formula can be used to determine the equivalent sound level [9]:

$$
L_{A e q, T}=10 \lg \left[\frac{1}{T} \sum_{i=1}^{n} \quad\left(t_{i} \cdot 10^{0,1 L_{A i(t)}}\right)\right] d B
$$

where:

- $\mathrm{L}_{\mathrm{Ai}}$ - instantaneous A-sound level at time $\mathrm{t}$,

- $\mathrm{n}$ - total number of measurements collected during the observation of $\mathrm{T}$.

The above formula, taking into account that the measurement time is equal to the train travel time, can be written as:

$$
L_{A e q, T_{p}}=10 \lg \left[\frac{1}{T_{p}} \sum_{i=1}^{n} \quad\left(t_{i} \cdot 10^{0,1 L_{A i(t)}}\right)\right] d B
$$

where:

- $\mathrm{L}_{\mathrm{Ai}}$ - instantaneous A-sound level at time $\mathrm{t}$,

- $\mathrm{n}$ - total number of measurements collected during the train journey $T_{p}$.

In the further part of our article, when analyzing the noise level for the train passage, the authors use the formula No. 3 for the equivalent noise level and 
refer the obtained results to the required values shown in Table 1.

\section{TEST METHODOLOGY AND EXEMPLARY MEASUREMENT RESULTS WITH NON-CALIBRATED DEVICES}

To verify the thesis, laboratory measurements and measurements in the area adjacent to the railway track were carried out. The Sonopan SON-50 integrating sound level meter calibrated with the KA-10 pistophone (94dB, No. 1686) was used as a reference and calibration measurement - Fig. 2. The correct operation of the Sonopan SON-50 meter was also verified in the laboratory with the SVAN 912p meter with the module SV 08A.

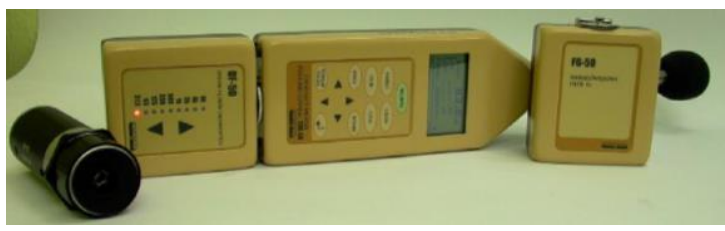

Fig. 2. SONOPAN SON-50 with a calibrator

Two models of phones from different manufacturers with the Android system, marked as "A" and "B", were used for measurements. As will be shown later in this article, software plays a particularly important role in measuring with the use of hardware. Already on the basis of preliminary research, it was found that the software should have the following functionalities:

- the ability to write to a file;

- possibility of introducing correction A,

- possibility of calibration.

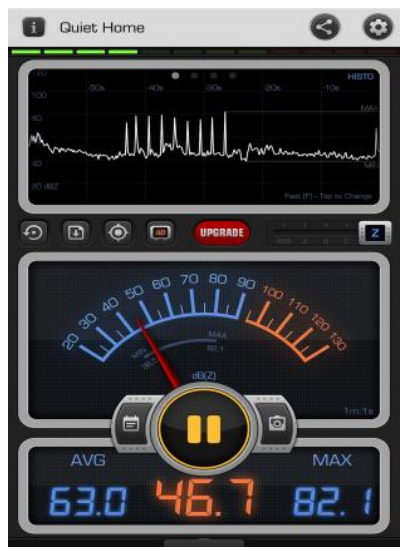

Fig. 3. Decibel X main screen

Of the above-mentioned functionalities, the most important thing to determine the correct sound pressure level in a given range is the ability to perform calibration. This calibration is possible only in a narrow group of programs and unfortunately it is only performed for a single measurement frequency. In order to select a program that meets the above-mentioned functionalities, a number of available applications were tested, and as a result of the preliminary tests, Decibel X Pro was selected.

\subsection{Laboratory measurements}

Laboratory measurements were used to determine the differences in indications between the two non-calibrated systems and the calibrated meter, which was the standard (Sonopan SON-50). In addition to comparative measurements, both smartphones were calibrated in dedicated software. In all measurements, a correction curve suitable for the measurements of noise of means of transport was used, i.e. curve A, therefore in the following considerations the measured sound pressure level will be expressed by the sound level in $\mathrm{dB}$. It is advisable to indicate the distance from the source, which for laboratory tests was $0.10 \mathrm{~m}(10 \mathrm{~m}$ in field tests). According to the manual, the frequency of recording the measurement result depends on the settings, ie: SLOW - every 500ms or FAST every $200 \mathrm{~ms}$, which means the frequency of 2 or $5 \mathrm{~Hz}$. In fact, it was determined that the program writes the time base incorrectly and to obtain the real measurement recording time, the saved time intervals should be multiplied by the constant 1,086 . The declared recording frequency of $5 \mathrm{~Hz}$, and even more so the real (after taking into account the constant 1,086) $4.6 \mathrm{~Hz}$, is insufficient to carry out most of the analyzes used in machine diagnostics. During the laboratory tests, the readings of the Sonopan Son-50 meter and the "A" and "B" phones for different sound frequencies were compared.

Table 1. Summary of indications before calibration

\begin{tabular}{|c|c|c|c|c|c|}
\hline \multirow{2}{*}{$\begin{array}{c}\text { Sound } \\
\text { frequency Hz }\end{array}$} & \multicolumn{5}{|c|}{ Sound level, dB(A) } \\
\cline { 2 - 6 } & Sonopan & “A” & Difference & “B” & Difference \\
\hline 100 & 70,2 & 72,8 & 2,6 & 70,3 & 0,1 \\
\hline 200 & 89,2 & 98,8 & 9,6 & 101,2 & 12 \\
\hline 300 & 88,9 & 101,7 & 12,8 & 100,6 & 11,7 \\
\hline 400 & 89,4 & 103,4 & 14 & 101,8 & 12,4 \\
\hline 500 & 84,8 & 101,4 & 16,6 & 92,9 & 8,1 \\
\hline 600 & 84,7 & 101,2 & 16,5 & 93,2 & 8,5 \\
\hline 700 & 68,3 & 85,9 & 17,6 & 73,6 & 5,3 \\
\hline 800 & 63,4 & 79,3 & 15,9 & 74,6 & 11,2 \\
\hline 900 & 75,4 & 90,9 & 15,5 & 81,3 & 5,9 \\
\hline $\mathbf{1 0 0 0}$ & $\mathbf{8 0 , 1}$ & $\mathbf{9 5 , 8}$ & $\mathbf{1 5 , 7}$ & $\mathbf{8 9 , 6}$ & $\mathbf{9 , 5}$ \\
\hline 1100 & 85,7 & 101,3 & 15,6 & 88,9 & 3,2 \\
\hline 1200 & 85,7 & 101,8 & 16,1 & 88,6 & 2,9 \\
\hline 1300 & 88,5 & 103,4 & 14,9 & 90,9 & 2,4 \\
\hline 1400 & 90,2 & 105,6 & 15,4 & 89 & $-1,2$ \\
\hline 1500 & 90,6 & 105,4 & 14,8 & 89,6 & -1 \\
\hline 1600 & 91 & 106,3 & 15,3 & 93,5 & 2,5 \\
\hline 1700 & 91 & 106,8 & 15,8 & 91,3 & 0,3 \\
\hline 1800 & 89,9 & 105,5 & 15,6 & 92,4 & 2,5 \\
\hline 1900 & 86,8 & 102,2 & 15,4 & 96,7 & 9,9 \\
\hline 2000 & 90,4 & 104,7 & 14,3 & 95,9 & 5,5 \\
\hline & & & & & \\
\hline
\end{tabular}

As can be read from Fig. 4, the one-point calibration allowed to obtain a very good correlation of the results with the standard in the range of $400 \div$ $1500 \mathrm{~Hz}$ for the telephone "A" - the difference with the standard does not exceed $1 \mathrm{~dB}$.

Calibration of the telephone "B" (Fig. 5) allowed to reduce the differences in the indicated sound level $\mathrm{dB}$, however, a reliable (less than $1 \mathrm{~dB}$ difference from the standard) measurement of sound intensity 
can be obtained only at the calibration point, i.e. $1000 \mathrm{~Hz}$.

Table 2. Measured values after one-point calibration

\begin{tabular}{|c|c|c|c|c|c|}
\hline \multirow{2}{*}{\begin{tabular}{|c|}
$\begin{array}{c}\text { Sound } \\
\text { frequency } \\
\mathrm{Hz}\end{array}$ \\
\end{tabular}} & \multicolumn{5}{|c|}{ Sound level, $\mathrm{dB}(\mathrm{A})$} \\
\hline & \begin{tabular}{|c|}
$\begin{array}{c}\text { Sonopa } \\
\mathrm{n}\end{array}$ \\
\end{tabular} & "A" & \begin{tabular}{|c|} 
Differenc \\
e
\end{tabular} & "B" & Difference \\
\hline 100 & 77,3 & 62,5 & 14,8 & 87,7 & $-10,4$ \\
\hline 200 & 91,2 & 83,9 & 7,3 & 94,8 & $-3,6$ \\
\hline 300 & 92,7 & 87,7 & 5 & 96,7 & -4 \\
\hline 400 & 89,3 & 87,4 & 1,9 & 91,7 & $-2,4$ \\
\hline $\begin{array}{ll}7 & 500 \\
\end{array}$ & 87,7 & 87,3 & 0,4 & 90,3 & $-2,6$ \\
\hline 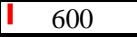 & 87,3 & 87,2 & 0,1 & 89,4 & $-2,1$ \\
\hline 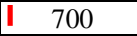 & 87,3 & 87,2 & 0,1 & 85,6 & 1,7 \\
\hline 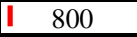 & 87,3 & 87,2 & 0,1 & 89,3 & -2 \\
\hline | 900 & 87,5 & 87,4 & 0,1 & 86,7 & 0,8 \\
\hline \begin{tabular}{|l|l|}
1000 \\
\end{tabular} & 88,6 & 88,5 & 0,1 & 88,7 & $-0,1$ \\
\hline 1 1100 & 90 & 89,4 & 0,6 & 89,1 & 0,9 \\
\hline $1 \quad 1200$ & 91,4 & 90,7 & 0,7 & 89,2 & 2,2 \\
\hline | 1300 & 91,6 & 90,7 & 0,9 & 85,2 & 6,4 \\
\hline $1 \quad 1400$ & 90,7 & 90,1 & 0,6 & 81,7 & 9 \\
\hline 1500 & 90,3 & 88,5 & 1,8 & 87,7 & 2,6 \\
\hline 1600 & 91,6 & 90,8 & 0,8 & 91,1 & 0,5 \\
\hline 1700 & 91,4 & 89,6 & 1,8 & 89,2 & 2,2 \\
\hline 1800 & 92,2 & 89,6 & 2,6 & 91,8 & 0,4 \\
\hline 1900 & 91,9 & 90,1 & 1,8 & 94,9 & -3 \\
\hline 2000 & 94 & 92,4 & 1,6 & 96,1 & $-2,1$ \\
\hline
\end{tabular}

If we assumed the threshold of $2.5 \mathrm{~dB}$ of the difference of indications, the measurement range would be from $600 \mathrm{~Hz}$ to $1200 \mathrm{~Hz}$. The telephone "B" can be used for simplified measurements only with multi-point calibration and in a significantly limited range of operating frequency.

Such a reduced range of operating frequencies will significantly limit the possibility of using this phone model for diagnostics or even railway vehicle detection.

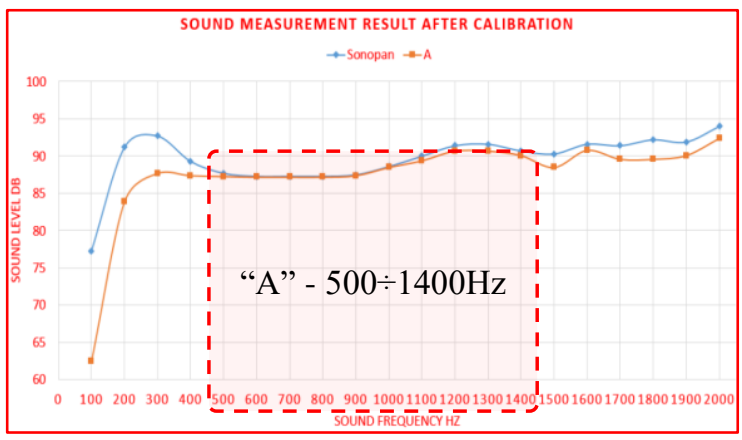

Fig. 4. Summary of the results of laboratory measurements after one-point calibration of the smartphone "A"

\subsection{Field measurements}

The field measurements were carried out in accordance with the normative requirements, however, due to safety requirements, the distance between the measuring point and the track was not kept $-7.5 \mathrm{~m}$ and $10 \mathrm{~m}$. However, it should be emphasized that all measurements were made at the same distance from the track. During the tests, the sound intensity level in $\mathrm{dB}(\mathrm{A})$ was recorded using the Decibel X Pro application. At the same time, the camera recorded the image, which was later used to determine the time of the train's passage and to identify the carriages included in the train. Based on the collected data, the average speed of the train was calculated. The measurement was carried out continuously and the results were exported to a format that could be read in Excel. The field survey covered 57 rail crossings, including EMU, passenger and freight trains, and the locomotives themselves.

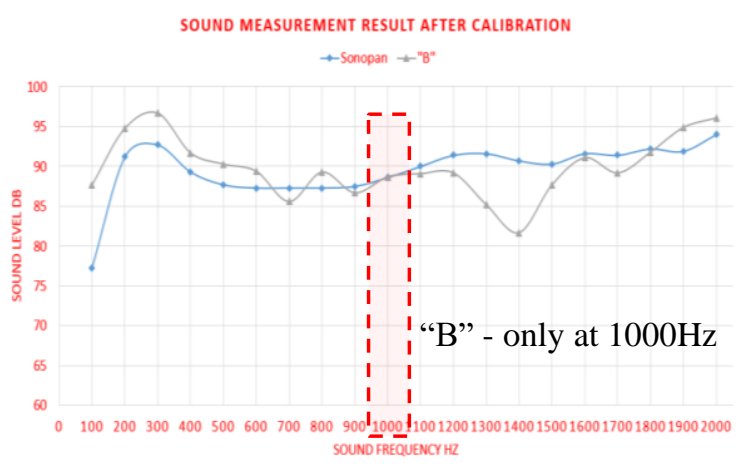

Fig. 5. Summary of the results of laboratory measurements after one-point calibration of the smartphone "B"

An exemplary calculation course was presented on the basis of data obtained during 9 measurement series of 01.06 concerning the EMU EN57 train run. The train passage occurred from 403.24 to 408.15 seconds of measurement.

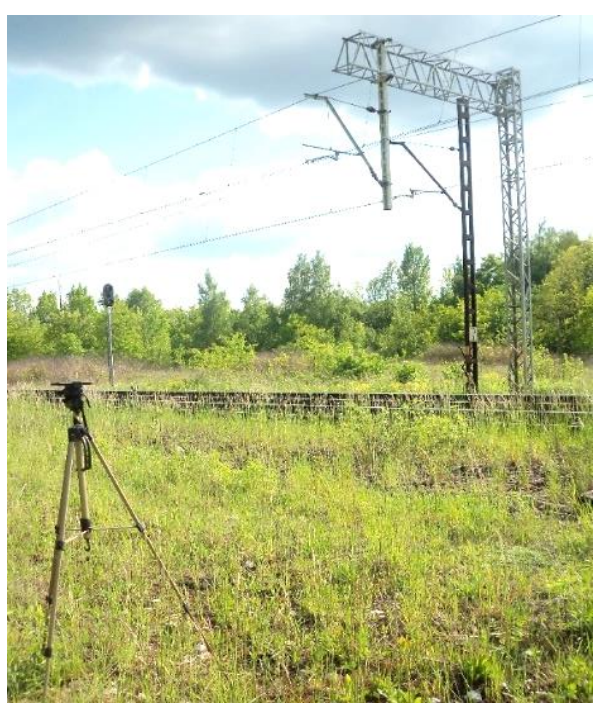

Fig. 6. Location of the measuring point at the railway line No.131 in 13,5 km [21]

When calculating the equivalent noise level $L_{A e q, T_{p}}$ the points most coinciding with this time were taken into account. The determined measurement time was $4.91 \mathrm{~s}$ and included 23 measurement results in total (Tab. 3).

On the basis of the data presented in Table 3, it was calculated that the equivalent noise level during the train passage was: $80,48 \mathrm{~dB}$ (measurement including calibration). 
$\mathrm{L}_{\mathrm{Aeq}, \mathrm{T}_{\mathrm{p}}}=10 \lg \left[\frac{1}{\mathrm{n}} \sum_{\mathrm{i}=1}^{\mathrm{n}}\left(10^{\left.0,1 \mathrm{~L}_{\mathrm{Ai}}\right)}\right]=10 \lg \left[\frac{1}{25} \cdot 2790000215\right]=80,48 \mathrm{~dB}\right.$

The conducted field tests were aimed at determining the scope of the possibility of using smartphones to measure the value of the equivalent sound level $L_{A e q, T_{p}}$ in accordance with the normative requirements (table 1 ).

Table 3. Part of the measurement data after calibration

\begin{tabular}{|l|c|c|}
\hline $\boldsymbol{L}_{A i}, \boldsymbol{d B}(\boldsymbol{A})$ & $\boldsymbol{T}, \boldsymbol{s}$ & $\mathbf{1 0} \mathbf{0}^{\mathbf{1}} \boldsymbol{L}_{\boldsymbol{A i}}$ \\
\hline 71,3 & 403,12 & $1,349 \mathrm{E}+07$ \\
\hline 74,6 & 403,34 & $2,884 \mathrm{E}+07$ \\
\hline 77,8 & 403,56 & $6,026 \mathrm{E}+07$ \\
\hline 80,5 & 403,77 & $1,122 \mathrm{E}+08$ \\
\hline 82,6 & 403,99 & $1,820 \mathrm{E}+08$ \\
\hline 82,3 & 404,21 & $1,698 \mathrm{E}+08$ \\
\hline 83,1 & 404,43 & $2,042 \mathrm{E}+08$ \\
\hline 82,7 & 404,64 & $1,862 \mathrm{E}+08$ \\
\hline 81,3 & 404,86 & $1,349 \mathrm{E}+08$ \\
\hline 81,1 & 405,08 & $1,288 \mathrm{E}+08$ \\
\hline 80,8 & 405,30 & $1,202 \mathrm{E}+08$ \\
\hline 81,3 & 405,51 & $1,349 \mathrm{E}+08$ \\
\hline 81 & 405,73 & $1,259 \mathrm{E}+08$ \\
\hline 81,1 & 405,95 & $1,288 \mathrm{E}+08$ \\
\hline 80,6 & 406,16 & $1,148 \mathrm{E}+08$ \\
\hline 80,7 & 406,38 & $1,175 \mathrm{E}+08$ \\
\hline 80,1 & 406,60 & $1,023 \mathrm{E}+08$ \\
\hline 80,4 & 406,82 & $1,096 \mathrm{E}+08$ \\
\hline 80,4 & 407,03 & $1,096 \mathrm{E}+08$ \\
\hline 80,3 & 407,25 & $1,072 \mathrm{E}+08$ \\
\hline 79,4 & 407,47 & $8,710 \mathrm{E}+07$ \\
\hline 79,4 & 407,68 & $8,710 \mathrm{E}+07$ \\
\hline 78,9 & 407,90 & $7,762 \mathrm{E}+07$ \\
\hline 78,7 & 408,12 & $7,413 \mathrm{E}+07$ \\
\hline 78,6 & 408,34 & $7,244 \mathrm{E}+07$ \\
\hline & $\Sigma$ & $\mathbf{2 , 7 9 0 E}+09$ \\
\hline
\end{tabular}

Based on the measurement, it can be determined that the tested vehicle (old type) slightly exceeds the requirements specified in Table 3 in terms of the acceptable sound level, i.e. $80 \mathrm{~dB}$. At the same time, it should be noted that the measurement was performed with an non-calibrated instrument, calibrated on the basis of a meter with an error of $1 \%$, i.e. 1.3 , for the $130 \mathrm{~dB}$ range, which allows to state that the result is within the measurement error range. Thus, it can be seen that even small values of the measurement uncertainty characterizing the meter may cause serious problems when it is necessary to clearly indicate "exceeded" or "normal".

In the analysis of the signal from the measuring device, an important parameter is also its ratio of the level before the forcing (noise) to the level after the SNR (signal to noise) forcing.

By analyzing the data presented in Fig. 5, it can be concluded that the signal-to-noise ratio is SNR = 1,82 [-]. For each vehicle, it was also possible to determine the speed of the journey, assuming that it was a constant speed during the entire journey through the measuring point. The lengths of trainsets were determined on the basis of the data contained in the literature on the construction of rail vehicles.
For the example considered above, with the EMU EN57 length of $64,77 \mathrm{~m}$, the train speed was:

$$
\mathrm{V}=\frac{\mathrm{s}}{\mathrm{t}}=\frac{64,77 \mathrm{~m} \cdot \frac{1 \mathrm{~km}}{1000 \mathrm{~m}}}{4,91 \mathrm{~s} \cdot \frac{1 \mathrm{~h}}{3600 \mathrm{~s}}}=47,49 \mathrm{~km} / \mathrm{h}
$$

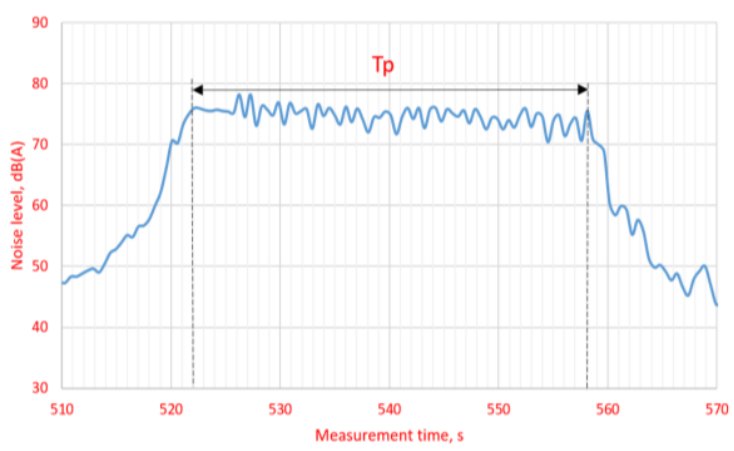

Fig. 7 Graph of changes in noise level during a run of a train with covered carbons (7.11-5 series) [21]

The diagram below (fig. 8) shows the dependence of the noise level on the speed of passing trains. Thus, it can be seen that despite the use of a non-calibrated system and prior to calibration, it is possible to determine the general relationship between the speed of vehicles (of various types, as well as empty and laden) and the noise level. As mentioned before, accurate sound level measurement requires a calibration of the measurement system.

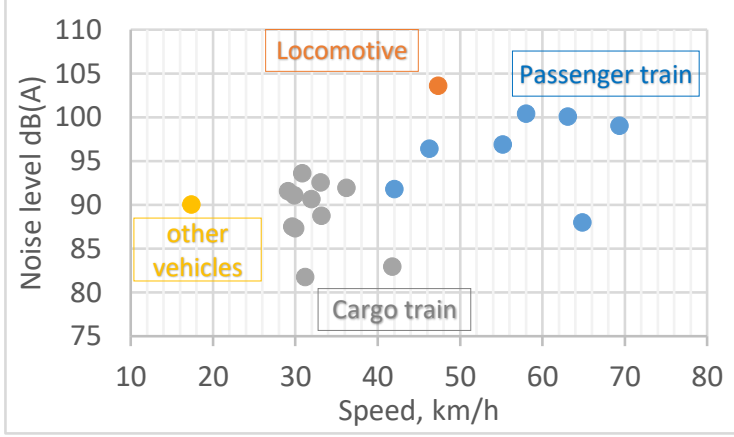

Fig. 8. Graph of the dependence of the noise level on the speed of travel obtained on the basis of the results recorded with "A" (data before calibration $-15,7 \mathrm{~dB}$ ) [21]

The basic method of using noise measurement systems is the cyclical measurement of the permissible sound level of railway vehicles operated on the railway network throughout the European Union. Requirements in this area are defined, inter alia, by TSI (Technical Specifications for Interoperability). This type of testing is performed both at the stage of prototype testing, certification testing, in-service testing and during the implementation of cyclic checking measurements. In a broader sense, the measurement of noise in means of transport also includes the need for periodic implementation of noise maps in the vicinity of residential areas. The analyzed possibility of using smartphones for this purpose would significantly 
expand the possibilities and frequency of measurement while reducing the related costs. However, in this case the accuracy of the measurement plays a particularly important role. In addition to these types of applications, it is also possible to use non-calibrated noise measurement systems for diagnostic measurements or vehicle identification.

In field conditions, the sound intensity of a passing train was also measured with the SONOPAN SON-50 meter and, at the same time, with a smartphone after calibration - Fig. 9. The study showed that the difference in measurements was $0,8 \mathrm{~dB}$ - table 6 .

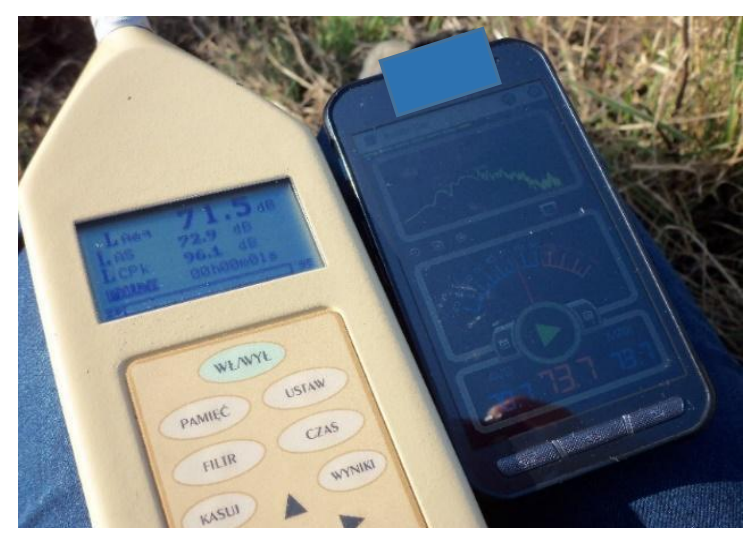

Fig. 9. Sonopan SON-50 and telephone [21]

Table 4. Data comparison between Sonopan SON-50 and the phone A after taking the calibration into account

\begin{tabular}{|c|c|c|}
\hline \multicolumn{2}{|c|}{$\begin{array}{c}\text { Instantaneous } \\
\text { noise value, } L_{A}, \\
\mathrm{~dB}(\mathrm{~A})\end{array}$} & $\begin{array}{c}\text { Equivalent noise } \\
\text { level during train } \\
\text { passage } \\
L_{\text {Aeq, } T_{p}}, \mathrm{~dB}(\mathrm{~A})\end{array}$ \\
\hline Sonopan & 72,9 & 71,5 \\
\hline „A" & 73,7 & 70,7 \\
\hline Difference & $-\mathbf{0 , 8}$ & $-\mathbf{0 , 8}$ \\
\hline
\end{tabular}

The obtained difference of $0.8 \mathrm{~dB}$ between the calibrated meter and the older generation smartphone after one-point calibration allow us to conclude that it is possible to define the area of use of this type of equipment while maintaining the indicated conditions of use, mainly calibration.

\section{ANALYSIS OF OBTAINED RESULTS}

\subsection{Low sampling rate and the ability to overcome this limitation}

When analyzing the obtained results of the verification tests, the first very serious limitation should be indicated, which was demonstrated already at the stage of preliminary tests, i.e. very low frequency of measurement data recording with high frequency of measurement. The actual recording frequency of $4,6 \mathrm{~Hz}$ means, for example, that during a journey of a freight train, $510 \mathrm{~m}$ long, consisting of 35 freight wagons and an ET22 locomotive at a speed of $30 \mathrm{~km} / \mathrm{h}$, the device will record 142 measurements during 30,83 s (7,5 measurements on coal wagon). This value is sufficient to compare the value of the equivalent noise level $\mathrm{L}_{\mathrm{Aeq}, \mathrm{Tp}} \mathrm{dB}$ during the passage of various types of trains at different speeds, etc. On this basis, it is also possible to detect the fact of a railway vehicle passing through and to determine its speed or direction of movement (if at least 2 measurement systems are used). Unfortunately, the measurement recorded with a frequency of $4,6 \mathrm{~Hz}$ does not allow for classical frequency analyzes.

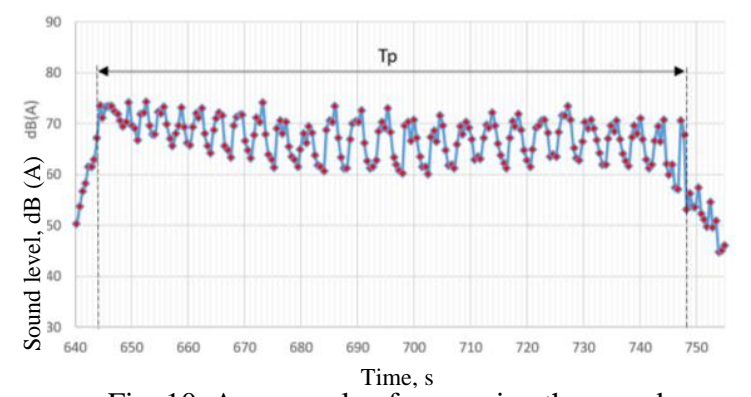

Fig. 10. An example of measuring the sound level with the telephone " $\mathrm{A}$ " during the travel of a locomotive and 26 wagons [21]

One of the possibilities to improve this situation is to implement the required analysis directly in the software of the non-calibrated system, because the computing power of currently produced smartphones is often many times greater than that of laptops, and the frequency of the measurement itself is similar to the frequency of professional meters. This solution would reduce the need to save data only to a single result of the assumed analysis. In the case of a freight train running at a low speed, it was even possible to estimate the number of wagons in the train composition, as the passing railway boogies with railway wheelsets generate additional noise, which is visible on the graph in the form of local maxima - fig. 10 .

Therefore, precise measurement is possible only when an appropriate analysis is implemented in the phone's measurement software, which usually has $15 \mathrm{kHz}$ sampling (less often $48 \mathrm{kHz}$ with a filter up to $22 \mathrm{kHz}$ ). Smartphone microphones most often use the operating frequency range of $300 \mathrm{~Hz}-15 \mathrm{kHz}$.

\subsection{Effective measurement frequency range}

For the use of microphones in smartphones, the most important are three frequency bands characteristic of the human voice, i.e.: first $85 \div 250 \mathrm{~Hz}$, second - the most important $350 \mathrm{~Hz}-$ $2 \mathrm{kHz}$ and third $1,5 \mathrm{kHz}$ do $4 \mathrm{kHz}$. The performed calibration showed that in the range from 500 to $1400 \mathrm{~Hz}$, the smartphone's microphone response without calibration is shifted parallel to the graph recorded by the SON-50 meter. After a one-point calibration, in the indicated frequency range $0,5 \div 1,4 \mathrm{kHz}$, the telephone "A" showed a difference in the measured sound level compared to the reference meter, less than $1 \mathrm{~dB}$. 
The limited range of "accurate" measurement obtained from the analysis is consistent with the observations of other researchers [4]. This means that if the measurement is performed to determine the sound level or its equivalent value, then if the sound source is within the indicated range - the measurement can be considered reliable for most purposes of comparative measurements, e.g. for comparing the sound level generated by different vehicles, etc. In the case of an attempt to calibrate the telephone "B", it was found that the compliance below $1 \mathrm{~dB}$ of the difference with the standard occurs only for the calibration frequency. As a result, the use of this type of telephone is very limited as it does not allow for a reliable quantitative measurement but only for qualitative detection of sound level changes - e.g. vehicle detection.

\section{CONCLUSIONS AND DIRECTIONS FOR FUTURE WORK}

Based on the literature analysis and the authors' own research, the following conclusions can be made:

- the use of smartphones for the purposes of sound measurement and diagnostic analysis is possible, however, it requires the selection of an appropriate telephone, software and mandatory calibration;

- there is a possibility of a significant increase in the possibility of using smartphones for diagnostic purposes, but it requires the implementation of analysis methods into the software directly on the phone, as the analysis of the recorded data is significantly limited by a very low frequency of recording;

- the measurements of the sound level performed in the field clearly indicated the appearance of a railway vehicle with the $\mathrm{SNR}=1,82$. It was also possible to determine the travel time in front of the sensor. Most of the measurements made did not allow to determine the number of wagons in the train set due to the speed of the vehicle and the low frequency of recording the measurement results and the considerable distance of the sensor from the track. However, there are measurements that allow to determine the number of wagons in a vehicle, but it was only possible for coal wagons moving at a relatively low speed;

- simultaneous field measurements of the sound intensity of a passing train with the SONOPAN SON-50 meter and a smartphone after calibration showed that the difference in measurements was $0,8 \mathrm{~dB}$. This allows us to conclude that it is possible to define areas where the use of a smartphone (especially a newer generation), after prior calibration, will enable a simplified measurement with a satisfactory measurement uncertainty.
- to sum up, the use of a smartphone for simplified sound measurement in non-laboratory applications, including diagnostic or comparative measurements, is possible provided that the following elements are provided as a minimum:

- selection of a smartphone with a wide range of linearity characteristics (in this example "A");

- selection of software that allows for calibration, recording in time with sufficient frequency or development of own program to perform the required diagnostic functions in real time;

- proper calibration (preferably multi-point, i.e. for the frequency and sound intensity range)

The directions for further work are considered to be the possibility of developing a proprietary program operating in the Android system and performing the functions of rail vehicle diagnostics in the field of detection of flat places (cyclical pulses) and braking squeaks as well as identification and counting of wagons based on the detection of rolling noise generated by railway wheelsets ).

The program should also enable multi-point calibration to be performed over a wide frequency range. It is necessary to define a set of telephone models that, similarly to the "A" model, will allow, after calibration, for a reliable measurement of the sound level. It should be noted that both phone models at the time of the measurement were not the leading models of their manufacturers.

\section{REFERENCES}

1. Geun-Hyo Kim, Duck-Hoon Kang, Yeon-Yoo Lee, Hyung-Soon Kim, Soon-Bok Kwon, Young-Seuk Cho, Hee-June Park, Yang-Gyu Choi,Bum-Joo Shin. Recording quality of smartphone for acoustic analysis. Journal of Clinical Otolaryngology. 2016; 27(2):286294. https://doi.org/10.35420/jcohns.2016.27.2.286

2. Grebenik J, Zhang Y, Bingham Ch, Srivastava S. Roller element bearing acoustic fault detection using smartphone and consumer microphones Comparing with vibration techniques. 17th International Conference on Mechatronics - Mechatronika (ME) 2016. INSPEC: 16638609.

3. Kardous C, Shaw P. Evaluation of smartphone sound measurement applications. The Journal of the Acoustical Society of America. 2014;4: 186-192, https://doi.org/10.1121/1.4865269.

4. Nast D, Speer W, Le Prell C. Sound level measurements using smartphone "apps": Useful or inaccurate?. Noise and Health. 2014; 14(72): 251-256.

5. Metod Celestina, Chucri A. Kardous, Andrej Trost: Smartphone-based sound level measurement apps: Evaluation ofdirectional response, Applied Acoustics. 2018; 139:119-128, https://doi.org/10.1016/j.apacoust.2018.04.011.

6. Metod Celestina, Jan Hrovat, Chucri A. Kardous: Smartphone-based sound level measurement apps: Evaluation of compliancewith international sound level meter standards. Applied Acoustics. 2018; 139: 119-128. https://doi.org/10.1016/j.apacoust.2018.04.011.

7. Biswas S, Bhattacharya T, Saha R. On fall detection using smartphone sensors. 2018 International 
Conference on Wireless Communications, Signal Processing and Networking (WiSPNET). 2018. https://doi.org/10.1109/WiSPNET.2018.8538688.

8. Su X, Tong H, Ji P. Activity recognition with smartphone sensors. Tsinghua science and technology. 2014; 19(3):235-249.

9. Hernández D, Marty J, Muñoz Guerrero R. Smartphone as a portable detector, analytical device, or instrument interface. Intechopen. 2017. https://doi.org/10.5772/intechopen.69678.

10. Pawar K, Jagtap S, Bhoir S. Efficient pothole detection using smartphone sensors. ITM Web Conf. International Conference on Automation, Computing and Communication. 2020.

https://doi.org/10.1051/itmconf/20203203013.

11. Kirci P, Saglamoz S, Sener M. An intelligent vehicle detection management model for parking spaces. Scientific Journal of Silesian University of Technology. Series Transport. 2018; 98: 35-43. https://doi.org/10.20858/sjsutst.2018.98.4.

12. Michta A, Haniszewski T. Traffic noise experienced on buses, trams and cars in the urban agglomeration of the city of Katowice. Scientific Journal of Silesian University of Technology. Series Transport. 2018:98: 101-109. https://doi.org/10.20858/sjsutst.2018.98.10.

13. Wróblewska D. Techniczne specyfikacje interoperacyjności dotyczące hałasu od pojazdów kolejowych. TTS. 2007;4:52-57.

14. Dyrektywa Rady 96/48/WE z dnia 23 lipca 1996 r. w sprawie interoperacyjności transeuropejskiego systemu kolei dużych prędkości.

15. Dyrektywa 2001/16/WE z dnia 19 marca 2001 r. w sprawie interoperacyjności transeuropejskiego systemu kolei konwencjonalnych.

16. Rozporządzenie wykonawcze Komisji (UE) 2019/774 z dnia 16 maja 2019 r. zmieniające rozporządzenie (UE) $\mathrm{nr} \quad 1304 / 2014 \mathrm{w}$ zakresie stosowania technicznych specyfikacji interoperacyjności podsystemu „Tabor kolejowy - hałas” w odniesieniu do istniejących wagonów.

17. http://www.ikolej.pl/seminaria-instytutu-kolejnictwa/ seminaria-szczegoly/zmiany-w-tsi-dotyczace-halasu.

18. ISO 3095:2013 Acoustics - Railway applications Measurement of noise emitted by railbound vehicles.

19. PN-EN ISO 3381 Railway applications - AcousticsMeasurement of noise inside railbound vehicles.

20. Kirpluk M, Wojciechowska E. Terminy i definicje dotyczące wyznaczania poziomu hałasu emitowanego przez pojazdy szynowe wg EN ISO 3095. Pojazdy Szynowe. 2008; 2:42-48.

21. Kula A. Analiza możliwości wykorzystania systemów niewzorcowanych do pomiarów porównawczych hałasu w transporcie szynowym. Projekt inżynierski, promotor Adam Mańka, Politechnika Śląska, 2021.

Received 2020-10-29

Accepted 2021-02-10

Available online 2021-02-11

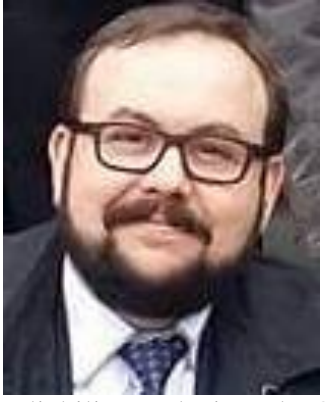

Adam MAŃKA absolvent of Silesian University of Technology, since 2001 researcher in the Department of Railway Transport, Faculty of Transport and Aviation Engineering. The author's main research interests are related to transport, in particular rail transport, including aspects of RAMS reliability analysis and LCC costs, risk analysis, designing rail vehicle components, implementation and analysis of vibration and noise measurements, testing temperature distributions and modeling thermal-coupled phenomena in FEM.

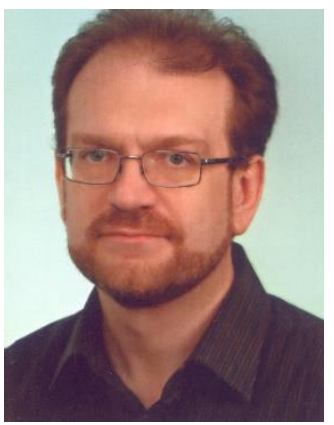

Andrzej HELKA absolvent of Silesian University of Technology, since 2000 researcher in the Department of Railway Transport, Faculty of Transport and Aviation Engineering. The main research interests of the author related to diagnostics and operation of rail vehicles. $\mathrm{He}$ has carried out many research works on the acceptance of railway vehicle components for use.

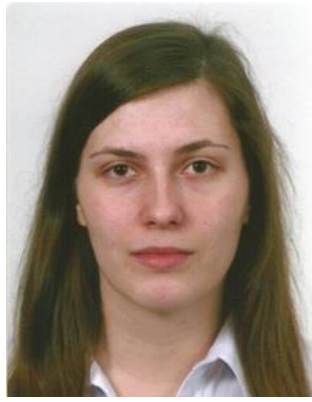

Anna KULA graduated from the Faculty of Transport and Aviation Engineering Silesian University of Technology, specialization: Construction and Operation of Rail Vehicles. Professional interests include with noise measurement in rail transport with the use of innovative technical solutions, including the use of non-calibrated systems. 